\title{
Quantitative trait loci for udder conformation and other udder traits in Finnish Ayrshire cattle
}

\author{
Nina F. Schulman, Sirja M. Viitala, Johanna H. Vilkki \\ MTT Agrifood Research Finland, Biotechnology and Food Research, FI-31600 Jokioinen, Finland, \\ e-mail:nina.schulman@mtt.fi
}

\begin{abstract}
Udder traits are important due to their correlation with clinical mastitis which causes major economic losses to the dairy farms. Chromosomal areas associated with udder conformation traits, milking speed and leakage could be used in breeding programs to improve both udder traits and mastitis resistance. Quantitative trait loci (QTL) mapping for udder traits was carried out on bovine chromosomes (BTA) 9, 11, 14, 18, 20, 23, and 29, where earlier studies have indicated QTL for mastitis. A granddaughter design with 12 Ayrshire sire families and 360 sons was used. The sires and sons were typed for 35 markers. The traits analysed were udder depth, fore udder attachment, central ligament, distance from udder to floor, body stature, fore teat length, udder balance, rear udder height, milking speed, and leakage. Associations between markers and traits were analysed with multiple marker regression. Five genome-wise significant QTL were detected: stature on BTA14 and 23, udder balance on BTA23, rear udder height on BTA11, and central ligament on BTA23. On BTA11 and 14 the suggested QTL positions for udder traits are at the same position as previously detected QTL for mastitis and somatic cell count.
\end{abstract}

Key-words: Quantitative trait loci, udder conformation, dairy cattle

\section{Introduction}

Dairy cattle breeding has traditionally focused on the improvement of production traits. Recently other traits such as udder health, fertility, and conformation have become more important since mastitis and fertility disorders are increasing among high yielding cows causing major economic losses to the dairy industry. Among all culling cases in Finnish Ayrshire $22.1 \%$ was due to mastitis, $21.4 \%$ due to fertility disorders, and $7.8 \%$ due to poor udder conformation in 2006 (Jukka Pösö, personal communication, 2007). When the replacement costs are estimated to be close to $30 \%$ of the total variable 
Vol. 16 (2007): 170-176

costs for milk production (Enroth 2006), clear savings could be obtained with improvement of these traits. Udder conformation traits have been shown to be related to udder health (Rogers and Hargrove 1990, Rupp and Boichard 1999). For example cows with higher udders, closer teat placement, and shorter teats are less likely to have high somatic cell count (SCC) (Rogers and Hargrove 1990). Stronger central ligament, higher udder depth, higher fore udder attachment and better udder balance are associated with less clinical mastitis (Rupp and Boichard 1999, Lund et al. 1994). Good udder conformation is also important for an easy and uniform milking routine, which is especially needed with automatic milking. Milking speed and leakage are other traits of the udder that also are correlated with udder health. Fast milking speed is associated with increased SCC but the relationship with mastitis is unclear (Rupp and Boichard 1999).

During the last 15 years several quantitative trait loci (QTL) mapping experiments have been undertaken (Khatkar et al. 2004). The final objective of these studies is to locate genes or linked markers that can be used in the breeding scheme to improve the economically important traits. Most of the detected QTL are affecting milk production traits and a few papers are dealing with other traits of dairy cattle. Especially the functional traits would benefit from marker-assisted selection because they are often traits that have low heritability and /or are difficult to measure and the genetic gain with traditional breeding schemes has been moderate. Udder conformation QTL have earlier been detected mainly in Holstein cattle (Schrooten et al. 2000, Boichard et al. 2003, Hiendleder et al. 2003). Quantitative trait loci for several conformation traits seem to be clustering on the same chromosomes, especially BTA6, 19, and 28. However, the QTL are not very consistent between studies. Putative QTL for milking speed have also been found on many chromosomes but none of them are observed in more than one investigation (Schrooten et al. 2000, Boichard et al. 2003, Hiendleder et al. 2003).

In a previous analysis with an Ayrshire cattle granddaughter design QTL for SCC and mastitis were detected (Schulman et al. 2004). The objective of the present study was to investigate if QTL for udder conformation, milking speed and leakage of milk are located on the same chromosomes where udder health QTL were earlier detected.

\section{Material and methods}

\section{Phenotypes and animals}

The analysed traits were stature (ST), fore teat length (FTL), udder balance (UB), rear udder height (RUH), udder depth, distance between udder and floor (DUF), central ligament (CL), fore udder attachment, milking speed (MS), and leakage. Udder balance means the balance of the udder from the side view, RUH is the distance of the udder to the vulva, udder depth is the relative distance of the udder from the tarsal joint, $\mathrm{CL}$ is the depth of the central ligament of the udder, and fore udder attachment is measuring the angle between the udder and the abdomen. Among the 10 traits analysed FTL, UB, RUH, udder depth, DUF, and CL are measuring different aspects of udder conformation. Stature is measuring the size of the cow, and it is related to the udder conformation traits. For example a bigger cow tends to have longer distance from udder to floor. Milking speed and leakage are functional traits of the udder. The conformation traits were scored subjectively by field advisors of the breeding organization. The scoring is done on a linear scale except for distance between udder and floor which is measured directly as the distance in $\mathrm{cm}$ from the rear teats to the floor. Milking speed indicates how fast the cow can be milked and leakage the tendency to leak milk before milking. The scoring of these two traits is based on the judgement of the farmer. Heritabilities of the traits range form 0.07 to 0.61 (J. Pösö, Finnish Animal Breeding Association, personal communication, 2007) (Table 1). Estimated breeding values (EBV) from the spring evaluation 2004 were obtained from the Finnish Animal Breeding association. Estimated breeding value for conformation traits were computed using animal model, repeatability model BLUP. Estimated breeding value for milking speed and leakage were estimated using a BLUP sire model. 


\section{AGRICULTURAL AND FOOD SCIENCE}

Schulman, N. et al. Udder trait QTL in Finnish Ayrshire

Table 1. Heritabilities of the analysed traits.

\begin{tabular}{ll}
\hline Trait & Heritability \\
\hline Stature & 0.61 \\
Front teat length & 0.38 \\
Udder balance & 0.22 \\
Rear udder height & 0.27 \\
Udder depth & 0.32 \\
Distance udder to floor & 0.42 \\
Central ligament & 0.22 \\
Fore udder attachment & 0.28 \\
Milking speed & 0.20 \\
Leakage & 0.07 \\
\hline
\end{tabular}

Data obtained from FABA Breeding (Jukka Pösö, personal communication).

A granddaughter design with 12 sire families was used in this study except for BTA20 where only 11 families were genotyped. These families are closely related to the families analysed in a previous whole genome scan (Viitala et al. 2003, Schulman et al. 2004). The total number of sons with breeding values for ST, FTL, UB, and RUH was 291 ranging form 18 to 40 sons per sire with an average of 24 sons. For the other traits the number of sons available was 360 ranging from 21 to 48 sons with an average of 30 sons. The number of daughters per son differed between the traits. For ST, FTL, UB, and RUH the median of the number of daughters was 40 and the mean 97, for udder depth, DUF, CL, and fore udder attachment the median was 34 and mean 80 , for MS and leakage the median was 81 and the mean 98 . The minimum number of daughters per son varied between different grandsire families from 6 to 37. Semen samples for DNA extraction were obtained from Finnish AI stations.

\section{Markers and genotypes}

Seven bovine chromosomes, BTA9, 11, 14, 18, 20, 23 and 29 were chosen for this study because QTL affecting mastitis and/or SCC have been detected on these chromosomes in previous studies (Boichard et al. 2003, Schulman et al. 2004, Holmberg and Andersson-Eklund 2004) and udder health traits are shown to be correlated with udder conforma- tion traits (Rupp and Boichard 1999). Two SNPs (growth hormone receptor and prolactin receptor) and 33 microsatellite markers were typed and linkage maps were computed using CRIMAP (Green et al. 1990). Number of markers per chromosome varied from 3 to 7 with an average spacing of 11 $\mathrm{cM}$. The average number of informative markers per chromosome ranged from 2 to 6 . The marker tables are available at http://www.mtt.fi/julkaisut/ cattleqtl. Methods of DNA extraction, PCR reaction protocols and electrophoresis are described by Vilkki et al. (1997) and Viitala et al. (2003, 2006).

\section{Statistical analysis}

The data was analysed using multiple linear regression (Knott et al. 1996). The analysis was done both between and within families. Chromosomes were analysed separately.

The model was: $y_{i j}=a_{i}+b_{i} x_{i j}+e_{i j}$, where $y_{i j}$ is the breeding value of bull $j$, who belongs to family $i, a_{i}$ is the polygenic effect for half-sib family $i, b_{i}$ is the allele substitution effect for a QTL within family $i, x_{i j}$ is the conditional probability for bull $\mathrm{j}$ of inheriting the first haplotype from sire $\mathrm{i}$, and $\mathrm{e}_{\mathrm{ij}}$ is the residual. The breeding value was regressed on the probability at $1 \mathrm{cM}$ intervals. The analysis was nested within families and the test statistic was an F-ratio. The breeding values were weighted for the number of daughters and the heritability of the trait.

Significance thresholds and P-values for the F statistic were obtained by permutation, which was repeated 10,000 times for each trait and chromosome separately (Churchill and Doerge 1994). Genome-wise P-values were obtained by Bonferroni correction $\mathrm{P}_{\text {genome }}=1-\left(1-\mathrm{P}_{\text {chromosome }}\right)^{29}$, where 29 is the number of bovine autosomes.

\section{Results and discussion}

Ten udder traits and 7 chromosomes were analysed in this mapping study. Five genome-wise significant 
Vol. 16 (2007): 170-176

QTL were detected: ST on BTA14 and 23, UB on BTA23, RUH on BTA11, and CL on BTA23. In addition, eight $5 \%$ and five $1 \%$ chromosome-wise significant QTL are of a suggestive nature. Genetic correlations between udder conformation traits are reported to be only moderate (Perttula 2007). Regarding this, it was somewhat surprising that several of the QTL were clustering on BTA11, 14 and 23 (Table 2). No QTL were found for udder depth and fore udder attachment. Also, no QTL were detected on BTA18. The false discovery rate of the analysis was calculated to be $19.4 \%((0.05 \times 10 \times$ $7) / 18$ ) which means that $1 / 5$ or 3.5 of the QTL are found by chance alone. The detected QTL should be regarded as preliminary results which should be confirmed in another independent experiment (Weller et al. 1998).

Quantitative trait loci for five of the analysed traits (FTL, UB, RUH, DUF, and CL) were located on BTA11 close to the markers BMS2569 and INRA177. The distance between these two markers was $25 \mathrm{cM}$. The QTL for RUH was genome-wise significant. There were 2 to 4 segregating families per trait on this chromosome. One family had significant F-values for FTL, UB, and RUH. The position of the highest value of the test statistic for this family was at the distal end of the chromosome for
UB and RUH and in the middle of the chromosome for FTL. The size of the QTL effects of the different traits among the significant families ranged from 0.52 to 1.58 standard deviations of EBV. The largest effects were detected for RUH and smallest for UB. No udder conformation trait QTL have previously been detected on BTA11.

On BTA14 we found QTL for ST, FTL, RUH, and DUF. The QTL for ST was genome-wise significant. QTL for ST and DUF seem to be located close to BMS740 and QTL for FTL and RUH between the markers BMS1747 and RM11. There were 2 to 3 families with significant QTL effects per trait on BTA14. The size of the QTL effects ranged from 0.68 to 1.55 standard deviations of EBV. The largest effects were detected for FTL and the smallest for ST. A QTL for ST has previously been detected on BTA14 close to marker BMS1941 (Spelman et al. 1999) which is $19 \mathrm{cM}$ from BMS740 on the MARC map (http://www. marc.usda.gov/genome/genome.html ). However, the confidence intervals are likely to be large in both studies and it may be the same QTL. Quantitative trait loci for ST, FTL, UB, DUF, CL, and MS were located on BTA23. The QTL for ST, $\mathrm{UB}$, and CL were genome-wise significant. There were 1 to 5 segregating families per trait on this

Table 2. Significance levels and locations of udder trait quantitative trait loci.

\begin{tabular}{|c|c|c|c|c|c|c|c|c|c|}
\hline \multirow[b]{2}{*}{ Trait } & \multicolumn{3}{|c|}{ BTA11 } & \multicolumn{3}{|c|}{ BTA14 } & \multicolumn{3}{|c|}{ BTA23 } \\
\hline & $\overline{\mathrm{P}_{\mathrm{chr}}{ }^{1}}$ & $\mathrm{P}_{\text {gen }}^{2}$ & Markers & $\overline{\mathrm{P}_{\mathrm{chr}}{ }^{1}}$ & $\mathrm{P}_{\text {gen }}^{2}$ & Markers & $\overline{\mathrm{P}_{\mathrm{chr}}{ }^{1}}$ & $\mathrm{P}_{\mathrm{gen}}^{2}$ & Markers \\
\hline Stature & & & & $<0.01$ & 0.01 & BMS740 & $<0.01$ & $<0.01$ & $\begin{array}{l}\text { BM1818- } \\
\text { BM1443 }\end{array}$ \\
\hline Front teat length & 0.03 & ns & $\begin{array}{l}\text { BMS2569- } \\
\text { INRA177 }\end{array}$ & 0.01 & ns & $\begin{array}{l}\text { BMS1747- } \\
\text { RM11 }\end{array}$ & $<0.01$ & ns & $\begin{array}{l}\text { BM1818- } \\
\text { BM1443 }\end{array}$ \\
\hline Udder balance & $<0.01$ & & $\begin{array}{l}\text { BMS2569- } \\
\text { INRA177 }\end{array}$ & & & & $<0.01$ & 0.01 & RM185 \\
\hline Rear udder height & $<0.01$ & $<0.01$ & BMS2569 & $<0.01$ & ns & $\begin{array}{l}\text { BMS1747- } \\
\text { RM11 }\end{array}$ & & & \\
\hline $\begin{array}{l}\text { Distance udder to } \\
\text { floor }\end{array}$ & 0.05 & ns & $\begin{array}{l}\text { BMS2569- } \\
\text { INRA177 }\end{array}$ & 0.02 & ns & $\begin{array}{l}\text { RM11- } \\
\text { BMS740 }\end{array}$ & 0.01 & ns & $\begin{array}{l}\text { RM185- } \\
\text { BM1818 }\end{array}$ \\
\hline Central ligament & 0.01 & ns & INRA177 & & & & $<0.01$ & 0.04 & $\begin{array}{l}\text { BM1818- } \\
\text { BM1443 }\end{array}$ \\
\hline Milking speed & & & & & & & 0.02 & ns & RM185 \\
\hline
\end{tabular}




\section{AGRICULTURAL AND FOOD SCIENCE}

Schulman, N. et al. Udder trait QTL in Finnish Ayrshire

BTA11

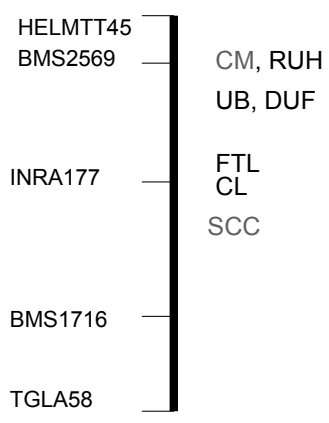

BTA14

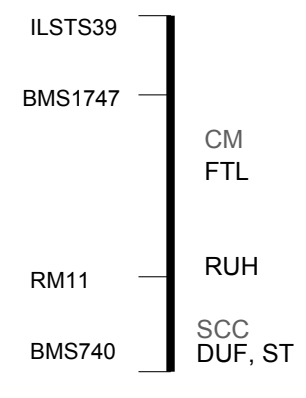

Fig. 1. Locations of quantitative trait loci (QTL) for udder traits and udder health traits on BTA11 and BTA14. The udder health QTL were detected in a previous whole genome scan of Finnish Ayrshire (Schulman et al. 2004). The abbreviations of the traits are $\mathrm{CM}=$ clinical mastitis, $\mathrm{RUH}=$ rear udder height, $\mathrm{UB}=$ udder balance, $\mathrm{DUF}=$ dis tance udder to floor, $\mathrm{FTL}=$ front teat length, $\mathrm{CL}=$ central ligament, $\mathrm{SCC}=$ somatic cell count, $\mathrm{ST}=$ stature.

chromosome. The size of the QTL effects ranged from 0.02 to 0.38 standard deviations of EBV. In a previous study with related animals, a QTL for live weight was detected between markers BM1258 and BoLA DRBP1 and a QTL for MS was suggested at the marker BoLA-DRBP1 (Elo et al. 1999). Live weight is related to ST because larger cows tend to have a higher live weight. These may be the same QTL as detected in the present study for ST and MS because the marker map in this study did not extend to the region of the chromosome with the earlier findings and because confidence intervals are likely to be large. Also, Ashwell et al. (2005) found a chromosome-wise suggestive QTL for ST in the proximal end of the chromosome and Schrooten et al. (2000) found a chromosome-wise significant QTL for MS between the markers BM1258 and GBCYP21. Further, Hiendleder et al. (2003) found a suggestive QTL for teat length at the distal end of BTA23.

Quantitative trait loci were also suggested on BTA9 for CL, on BTA20 for UB, and on BTA29 for leakage. All these putative QTL were located at the end of the linkage groups and they were significant

at the chromosome-wise level. A QTL for UB has previously been suggested on BTA20 but closer to the proximal end of the chromosome (Boichard et al. 2003).

As udder conformation traits are reported to be correlated with udder health traits (Rupp and Boichard 1999), it is of interest to see if QTL for both trait groups are detected on the same chromosome locations. When comparing the locations of the udder conformation QTL detected in the present study with QTL for udder health traits from a previous granddaughter design in the same breed, some overlapping areas were found (Fig. 1). A QTL for mastitis was detected on BTA11 close to the marker BM716 (Schulman et al. 2004). This marker is close to (2 cM apart on the MARC map) BMS2569 where a QTL for RUH was detected in the present study. Also, QTL for FTL, UB, and DUF were suggested in the marker interval next to BMS2569. In the previous study a QTL for SCC was detected close to the marker HELMTT41 which is $43 \mathrm{cM}$ from BMS2569 on the MARC map. On BTA14 a QTL for mastitis was previously detected between markers BMS1747 and RM011. This is the same area where a QTL for FTL was suggested in the present study and might indicate that the QTL that affects teat length indirectly affects also mastitis susceptability. High correlation between teat length and mastitis has been reported in the literature (Lund et al. 1994). A QTL for SCC was previously detected on BTA14 at the marker BMS740 which is close to the same position where QTL for ST and DUF were found in the present study. On BTA23 a QTL for SCC was suggested close to the marker RM033 in the previous granddaughter design, and in the present study, QTL for UB and MS were found close to marker RM185. The marker RM033 is closer to the proximal end of BTA23 on the MARC map than RM185 which is the first marker on the map of the present study. Therefore this same QTL may have an effect on UB and MS.

In conclusion, genome-wise significant QTL were detected on 3 of the 7 analysed chromosomes: stature on BTA14 and 23, udder balance on BTA23, rear udder height on BTA11, and central ligament on BTA23. In addition 13 chromosome-wise sig- 
Vol. 16 (2007): 170-176

nificant QTL were found. Several of the QTL were clustering on BTA11, 14 and 23. On BTA11 and 14 the suggested QTL positions for udder traits are overlapping with previously detected QTL for mastitis and SCC. Fine mapping of these areas could lead to the finding of new tools to improve both udder conformation and health.

Acknowledgements. We would like to thank FABA Breeding for providing the material for the study. Jukka Pösö from FABA Breeding is especially acknowledged for valuable information regarding the studied traits. This project has been partly funded by the Ministry of Agriculture and Forestry in Finland (project 310145, Mapping and selection of genes affecting productive age of dairy cows) and FABA Breeding.

\section{References}

Ashwell, M.S., Heyen, D.W., Weller, J.I., Ron, M., Sonstegard, T.S.,Van Tassell, C.P. \& Lewin, H.A. 2005. Detection of quantitative trait loci influencing conformation traits and calving ease in Holstein-Friesian cattle. Journal of Dairy Science 88: 4111-4119.

Boichard, D., Grohs, C., Bourgeois, F., Cerqueira, F., Faugeras, R., Neau, A., Rupp, R., Amigues, Y., Boscher, M.Y. \& Leveziel, H. 2003. Detection of genes influencing economic traits in three French dairy cattle breeds. Genetics Selection Evolution 35, 1: 77-101.

Churchill, G.A. \& Doerge, R.W. 1994. Empirical threshold values for quantitative trait mapping. Genetics 138 : 963-971.

Elo, K.T., Vilkki, J., de Koning, D.J., Velmala, R.J. \& MäkiTanila, A.V. 1999. A quantitative trait locus for live weight maps to bovine chromosome 23. Mammalian Genome 10: 831-835.

Enroth, A. 2006. Mallilaskelmia maataloudesta 2006. Pro Agria Maaseutukeskusten Liiton julkaisuja 1030. 46 p.

Green, P., Falls, K. \& Crooks, S. 1990. Documentation of CRIMAP, version 2.4. Washington University School of Medicine, St. Louis, MO.

Hiendleder, S., Thomsen, H., Reinsch, N., Bennewitz, J., Leyhe-Horn, B., Looft, C., Xu, N., Medjugorac, I., Russ, I., Kühn, C., Brockmann, G.A., Blümel, J., Brenig, B., Reinhardt, F., Reents, R., Averdunk, G., Schwerin, M., Förster, M., Kalm, E. \& Erhardt, G. 2003. Mapping of QTL for body conformation and behavior in cattle. Journal of Heredity 94, 6: 496-506.
Holmberg, M. \& Andersson-Eklund, L. 2004. Quantitative trait loci affecting health traits in Swedish dairy cattle. Journal of Dairy Science 87: 2653-2659.

Khatkar, M.S., Thomson, P.C., Tammen, I. \& Raadsma, H.W. 2004. Quantitative trait loci mapping in dairy cattle: review and meta-analysis. Genetics Selection Evolution 36: 163-190.

Knott, S.A., Elsen, J.M. \& Haley, C.S. 1996. Methods for multiple-marker mapping of quantitative trait loci in half-sib populations. Theoretical and Applied Genetics 93: 71-80.

Lund, T., Miglior, F., Dekkers, J.C.M. \& Burnside, E.B. 1994. Genetic relationships between clinical mastitis, somatic cell count, and udder conformation in Danish Holsteins. Livestock Production Science 39: 243-251.

Perttula, H. 2007. Ayrshire-ensikoiden maidontuotantoja utarerakenneominaisuuksien perinnölliset yhteydet. Pro gradu. Helsingin Yliopisto. 33.

Rogers, G.W. \& Hargrove, G.L. 1990. Correlations among linear type traits and somatic cell counts. Journal of Dairy Science 74: 1087-1091.

Rupp, R. \& Boichard, D. 1999. Genetic parameters for clinical mastitis, somatic cell score, production, udder type traits, and milking ease in first lactation Holsteins. Journal of Dairy Science 82: 2198-2204.

Schrooten, C., Bovenhuis, H., Coppieters, W. \& van Arendonk, J. A. 2000. Whole genome scan to detect quantitative trait loci for conformation and functional traits in dairy cattle. Journal of Dairy Science 8: 795-806.

Schulman, N.F., Viitala, S.M., de Koning, D.J., Virta, J., Mäki-Tanila, A. \& Vilkki J.H. 2004. Quantitative trait loci for health traits in Finnish Ayrshire cattle. Journal of Dairy Science 87: 443-449.

Spelman, R.J., Huisman, A.E., Singireddy, S.R., Coppieters, W., Arranz, J., Georges, M. \& Garrick D.J. 1999. Short Communication: Quantitative trait loci analysis on 17 nonproduction traits in the New Zeeland dairy population. Journal of Dairy Science 82: 2514-2516.

Viitala, S.M., Schulman, N.F., de Koning, D.J., Elo, K., Kinos, R., Virta, A., Virta, J.,Mäki-Tanila, A. \& Vilkki, J.H. 2003. Quantitative trait loci affecting milk production traits in Finnish Ayrshire dairy cattle. Journal of Dairy Science 86: 1828-1836.

Viitala, S., Szyda, J., Blott, S., Schulman, N., Lidauer, M., Mäki-Tanila, A., Georges, M. \& Vilkki, J. 2006. The role of the bovine growth hormone receptor and prolactin receptor genes in milk, fat and protein production in Finnish Ayrshire dairy cattle. Genetics 173: 2151-2164.

Vilkki, H.J., de Koning, D.J., Elo, K., Velmala, R. \& MäkiTanila, A. 1997. Multiple marker mapping of quantitative trait loci of Finnish dairy cattle by regression. Journal of Dairy Science 80: 198-204.

Weller, J.I., Song, J.Z., Heyen, D.W., Lewin, H.A. \& Ron, M. 1998. A new approach to the problem of multiple comparisons in the genetic dissection of complex traits. Genetics 150: 1699-1706. 


\title{
SELOSTUS
}

\section{Utareen rakenteeseen ja käyttöominaisuuksiin vaikuttavia geenialueita suomalaisessa ayrshirepopulaatiossa}

\author{
Nina F. Schulman, Sirja M. Viitala ja Johanna H. Vilkki \\ MTT Biotekniikka- ja elintarviketutkimus
}

\begin{abstract}
Lehmän utareen rakenne- ja käyttöominaisuudet ovat tärkeitä, koska ne vaikuttavat utareterveyteen ja hyvän muotoinen utare myös helpottaa lypsyä. Näiden ominaisuuksien geenialueita voitaisiin käyttää jalostusohjelmissa sekä utareen rakenteen että utaretulehdusalttiuden parantamiseksi. Niinpä tässä tutkimuksessa kartoitettiin naudan kromosomit 9, 11, 14, 18, 20, 23 ja 29, joista aikaisemmassa tutkimuksessa oli löydetty utareterveyteen vaikuttavia geenialueita.
\end{abstract}

Aineistona oli 12 suomalaista ayrshireperhettä, yhteensä 372 yksilöä. Kultakin yksilöltä tyypitettiin 35 geenimerkkiä. Tutkitut ominaisuudet olivat: utareen muoto, etukiinnitys, keskiside, maavara, takakorkeus, etuvedinten pituus, tasapaino, takakiinnityksen korkeus, lypsettävyys ja vuoto. Ominaisuuksien ja geenimerkkien väliset yhteydet analysoitiin monen markkerin regressiomenetelmällä.

Tutkimuksessa löydettiin viisi genomitasolla merkitsevää geenialuetta: takakiinnityksen korkeus kromosomissa 11, takakorkeus kromosomeissa 14 ja 23, sekä tasapaino ja keskiside kromosomissa 23. Lisäksi löydettiin 13 kromosomitasolla merkitsevää geenialuetta. Kromosomeissa 11 ja 14 löydetyt geenialueet ovat samoilla kohdilla kuin aiemmassa kartoitustutkimuksessa löydetyt utareterveyteen vaikuttavat geenialueet. Hienokartoittamalla nämä alueet saataisiin mahdollisesti uusia keinoja, joilla edistää utarerakennetta ja -terveyttä. 